\title{
Theoretical Aspects of Cartelization in Central Europe - An Introduction to Cartel Theory
}

\section{Lukáš NIKODYM}

\author{
Katedra hospodářských dějin, \\ Národohospodářská fakulta, Vysoká škola ekonomická v Praze \\ Department of Economic History, \\ Faculty of Economics, University of Economics in Prague, \\ nám. Winstona Churchilla 4, 13067 Praha, Czech Republic \\ nikodym.lukas@gmail.com
}

In contemporary economic theory, which is largely based on neoclassical economics, as well as in game-theory models and in the economics of the so-called Chicago school of economics, a cartel and similar market structures are considered to be a non-optimal market organization which is able to use its power in order to exclude its competitors or disadvantage consumers. A cartel is a market structure which has the ability to restrict competition through the use of price dumping, as well as to discriminate against consumers by increasing prices and in doing so draining off the consumer surplus which would otherwise be realized in a regular competitive structure. The purpose of economic theory, which is related to cartel theory, is to find a way to regulate cartels, to reduce their influence and power and to avoid their collusive actions.

One of the possible and traditional options is to prohibit cartel agreements as a whole, as has been the case in the United States since the 1880s. ${ }^{1}$ The combination of the liberal tradition and the neoclassical view of the market and competition which led to the maximum restraint of collusive behavior is especially typical for the United States and Great Britain. The circumstances in Europe, and Central Europe in particular, were entirely different. Neoclassical economic theory was not as dominant in this area in the last quarter of the $19^{\text {th }}$ Century as it was in Britain and the United States. ${ }^{2}$ We can therefore assume that the European view of the market and competition was also different, partially due to this fact. The chief issue by the end of the $19^{\text {th }}$ Century was the economic crisis which followed the

1 The United States and Great Britain also have a long tradition of antitrust laws which were established to regulate cartel agreements and similar market structures. Laws limiting such market cooperation were even adopted before cartel theory was fully described. In countries which held such a strong liberal tradition, cartels, trusts and monopolies were treated as market threatening subjects. This can be illustrated by using a speech given by Senator Sherman himself when defending his law. He argued in favor of saving the free market, competition and above all equal rights for all entrepreneurial subjects. His efforts culminated in the famous case of Standard Oil Co. vs. the United States from 1911. Standard Oil was divided into 34 smaller companies. See William KOVACIC - Carl SHAPIRO, Antitrust Policy: A Century of Economic and Legal Thinking, in: Journal of Economic Perspectives, 14, 2000, 1, 45.

2 Ludwig von MISES, The Historical Setting of the Austrian School of Economics, 2003, URL: http://mises.org/ etexts/histsetting.pdf (visited: June 2014). By the end of $19^{\text {th }}$ Century and the beginning of $20^{\text {th }}$ Century, so called Methodenstreit was taking place in Central Europe. This involved a dispute between the two dominant schools of economics at that time - the Austrian school of economics and the German historical school. While the German historical school refused classical economic thinking, the Austrian school criticized the neoclassical static theory of equilibrium. 
failure of the stock exchange in Vienna. Central European economic thought was therefore somewhat skeptical about free market structures.

The aim of this paper is to point out some of the confusion within Central European economic thought and also to mention some of the incorrect steps which have been taken as a result of economic policies based on incorrect theories. Economic thought, influenced by the course of economic crises, turned from its liberal traditions and the concept of methodological individualism to a more interventionist way of implementing economic policies in Central Europe.

The first section of this paper addresses economic crises which are often followed by cartelization. It also refers to a fundamental misunderstanding of the causes and course of business cycles and the insufficient theoretical framework.

The second section briefly summarizes the regulatory framework which includes cartel agreements. This section focuses on the regulation in period up to 1929, when the Great Depression commenced.

The third section addresses the economic assumptions for the establishment of a cartel. The frequently mentioned negative impacts of cartels are described at the beginning. This section also deals with the role of the state in the process of cartel creation and state protectionism in particular. The question of protectionism is followed by the possibility of a cartel setting pricing policy and in doing so creating barriers for those who would otherwise enter the market. Once the negative attitude towards cartels has been disproved, the question of regulation will arise.

The fourth section is all about regulation. Once the possibility of banning cartel agreements has been ruled out, the basic options for regulating cartels will be defined. The first option is to fully dispose of market barriers, while the second option is to implement forced cartelization. The hazards of forced cartelization are also explained, as are the benefits of the free market.

The fifth and final section briefly sums up the process of forced cartelization in Czechoslovakia, Germany and Austria during the 1930s. This section also points to the possible complete destruction of the market through forced cartelization which consequently simplifies the transition to a centrally planned economy.

\section{Economic Crises As a Prerequisite for Cartelization}

Economic and legal thought in Central Europe was mostly "locked" between two extreme positions. The free market was considered to be one of these extreme situations and the monopoly and cartel structure was the second. A cartel organization was understood to be the precursor of the monopoly structure and the free market was considered to be the cause of economic crises. ${ }^{3}$ Several reasons can be found as to why the market was considered to be the cause of crises. The "Founder Epoch" (Gründerzeit) which preceded the crisis of 1873 was connected with the expansion of entrepreneurial activities and the creation of the modern banking sector. The subsequent crisis was considered to be a

3 David MACGREGOR, Recent Papers on Cartels, in: The Economic Journal, 37, 1927, 146, 247-254. 
consequence of the previous boom in the free market. ${ }^{4}$ However, the main reason why the free market was associated with the economic crisis was due to a misunderstanding of the course of business cycles. It is now easy to show that the causes of the 1873 crisis were monetary. ${ }^{5}$ But at that time, there was no theoretical framework to understand and explain this phenomenon. ${ }^{6}$ Because of this theoretical gap, a crisis was usually interpreted as an overproduction crisis caused by the free market. In a situation where the market and competition could not match supply with demand (according to Central European economic theory of late $19^{\text {th }}$ Century), the cartel structure of industry became one of the possible solutions to resolve overproduction. Another explanation of business cycles was offered a few years later, for example, by Karel Engliš, who distinguished between rationalization and deflation crises. ${ }^{7}$

However, there are always practical consequences of economic crises, not only in the field of economic theory. Primarily, post-crisis protectionism (as a common tool of crisis solution) is very important in relation to the process of cartelization. The expansion of customs tariff policy was not only characteristic of the period after 1873, but historical experience has also shown that it is the common result of almost all crises. Policy development after 1929 (during the Great Depression) was no exception. Tariff policy aimed at protecting the domestic economy led to limited competition from foreign producers and created a suitable environment for the creation of cartels. Among economic and legal theorists there is no agreement as to whether customs tariffs are a result of government activity or a result of pressure brought to bear on the government by domestic producers. However, this disputation is not so important, because the preconditions for the cartelization process are created in both cases; both when the government acts on its own behalf and when it does so under pressure from producers. ${ }^{8}$ Moreover, it is possible to assume that the expansion of the tariff policy is the result of a combination of both factors.

The misunderstanding of the business cycle and the subsequent period of government protectionism is characteristic for the periods after the serious crises of 1873 and 1929. The conditions for the establishment of cartels were very similar and cartelization did actually occur in both cases. However, the way the cartels were created is also very important. Despite the fact that the conditions for their creation were similar, the processes were

4 Otakar ŠEVČík, Kartely, Praha 1913, 15.

5 Pavel KOHOUT, Finance po krizi: důsledky hospodářské recese a co bude dál, Praha 2009. According to the monetary theory of business cycles, it is possible to show that this crisis was caused by the war reparations after the Franco-Prussian War which corresponded to the influx of easy money.

6 The underlying literature on business cycles was published many years after the crisis of 1873. Knut Wicksell's work "Geldzins und Güterpreise" was published in 1898, while Ludwig von Mises published his "Theorie des Geldes und der Umlaufsmittel" in 1912.

7 Karel ENGLIŠ, Deflační a racionalisační krise, in: Obzor národohospodářský XXXVI, 1932, 1-24. Engliš’ approach lies between a Keynesian and a Monetarist approach. A rationalization crisis (growth of productivity) only increases pressure on shifting the purchasing power because of increasing unemployment, but a deflation crisis leads to a reduction in purchasing power. Deflation is then considered to be the cause of the crisis.

8 On the role of domestic producers in tariff policy, see for example Lev WINTER, Donucovací prostředky kartelu, in: Obzor národohospodářský XVIII, 1913, 31-36; Patrik PANEŠ - Josef ŠíMA, Výzvy antimonopolní politiky v 21. století, in: Acta Oeconomica Pragensia, 13, 2005, 3, 69-80. On the role of government action, see for example Karel VIŠKOVSKÝ, Zdražování životních potřeb, in: Obzor národohospodářský XII, 1907, 21-30, 82-87, 127-137, 171-178. 
different. After 1873, protectionism led to the creation of processes which can be considered to be endogenous within the framework of the market process, but after 1929 these processes were not spontaneous, but they were forced by the government. At first sight, the results can be considered to be similar or the same in the case of both spontaneous and forced cartelization. However, the same industrial structure does not imply the same industrial results, because the process of forced cartel creation is nothing other than a specific type of government regulation or legal privilege which significantly changes the cartel's motivation.

\section{The Regulatory Framework for Cartelization}

Forced cartelization represents the peak of government market regulation. It is, of course, possible to find attempts to regulate the market throughout the entire period between the aforementioned crises of 1873 and 1929. Similarly, there is also a trend towards government regulation within the framework of economic theory. ${ }^{9}$ Despite all the attempts to create a regulatory framework, governments were unsuccessful in adopting effective and comprehensive laws until the period of forced cartelization. ${ }^{10}$ Central European governments started to regulate cartels in the same period as the United States and Great Britain (the 1870s), but they were insufficient. In Austria, the first law regulating the pricing policy of cartels was created in 1870 (the so called 'Koalitiongesetz'). However, this law did not regulate all industries and it therefore did not have a general impact. The Czechoslovak legal framework was built on the foundations of the Austrian system which therefore resulted in the question of cartel regulation being equally inefficient. ${ }^{11}$ In Hungary, there was no special legal framework regulating cartels until the Great Depression and the regulation was based merely on the specific section of certain laws. ${ }^{12}$ The German legal framework was almost identical to the Hungarian legal framework. ${ }^{13}$ However, cartel agreements in Germany were legally binding, and therefore easy to enforce. In Central Europe, despite all the attempts, there was no comprehensive legal framework regulating cartels, which was also one of the important factors which led to cartel creation. The definitive solution to the question of regulation was forced cartelization during the first half of 1930s.

\footnotetext{
9 There was a call for the regulation of both the free market and cartel structures. As I mentioned before, economic thought in Central Europe was locked between two extremes considered to be the free market and the monopoly structure of industry.

10 Paul Thomas FISCHER - Horst WAGENFÜHR, Kartelle in Europa (ohne Deutschland), Nürnberg 1929.

$11 \mathrm{Ibidem}, 51$. Czechoslovak laws were based on Austrian laws from 1870. There were attempts to regulate cartels between 1925 and 1926, but the true regulation began in 1928 - one year before the Great Depression started (Gesetz über den unlauteren Wettbewerb).

12 Ibidem, 62-63. For example, cartels were regulated by means of section 162 of the Industriegestz from 1884 or section 128 of the Strafgesetzbuch from 1879.

13 ŠEVČík, 63. Germany also had no comprehensive legal framework which only regulated cartels. There was the option of using, for example, a section from the Civil Code regulating usury or bullying. However, the most important fact is that there was no regulation of price setting in Germany, even in the case of cartel structures in industry. It is also interesting that the Protection of Competition Act was adopted in Germany in 1896, but this law was never used due to its serious inadequacies. The Austrian government tried to pass a similar law, but it was unable to get the law passed in the period from 1901 to 1908, when it was finally rejected.
} 


\section{The Negative Consequences of Cartelization}

The question remains, however, if any regulatory framework is able to stop a cartel from engaging in collusive behavior and what the impacts of such regulation are? The need for cartel regulation or the prohibition of cartels completely is based on particular assumptions of economic theories which show how cartels subdue competition, exclude it from the market or disadvantage consumers. These theories are characteristic for the area of Central Europe and they also perceive free competition as negatively as an unregulated cartel. While a cartel without regulation is able to set prices and thus to push prices upwards, the fragmentation of the market in the case of free competition leads to increased costs for coordinating demand and supply, which therefore leads to the same conclusion. According to the economic thought of that time, both of these situations led to price increases and cartel regulation therefore seemed to be an optimal solution. ${ }^{14}$ This is the main difference between Anglo-American and Central European economic thought. Anglo-American economic thought tried to find a different way of protecting free competition than cartel regulation. Almost none of the European economists understood all of the imperfections and dangers of regulation. ${ }^{15}$

There are actually several types of cartels. There is a conditional cartel, a price cartel or a reducing cartel. ${ }^{16}$ The key assumption is that all cartels are based on a voluntary agreement between producers. The next assumption concerns the intentions of cartels. The point is to set prices, hold down production and in doing so monopolize the whole industry. ${ }^{17}$ The economic assumptions for cartel creation are equally important, because not all industries are suitable for a cartel structure. The economic assumptions are as follows: a small number of producers with a significant market share, a relatively homogenous product, the existence of economies of scale and lower elasticity of demand or possible barriers to entering the market. The assumptions for the creation of cartels are many and the one which is chosen depends on the particular theoretical framework. ${ }^{18}$ It is then possible to infer the specific tools which the cartels use from these theoretical preconditions. Cartels use these tools, such as price agreements in relation to competitors and consumers, production constraint agreements, the creation of market entry barriers and the suppression of competition, to

14 See VIŠKOVSKÝ, 26; Ervín HEXNER, Československé kartely, Praha 1933, 4-6.

15 Rudolf HOTOWETZ, Kartely a stát, in: Obzor národohospodářský II, 1897, 209-212. Hotowetz pointed out the deficiencies of bureaucratic control which does not have enough information available. He essentially described Stigler's regulatory capture. See: George STIGLER, The Theory of Economic Regulation, in: The Bell Journal of Economics and Management Science, 2, 1971, 1, 3-21.

16 ŠEVČík, 29-47. There are also other types of cartels, for example consumer cartels, however only production cartels are important for the purpose of this analysis. These cartels bring producers together.

17 Frederic M. SCHERER - David ROSS, Industrial Market Structure and Economic Performance, Boston 1990, 226.

18 For a survey of economic theories and cartel policies and market structures, see for example lan AYRES, How Cartels Punish: A Structural Theory of Self-Enforcing Collusion, in: Columbia Law Review, 87, 1987, 295-325; Malcolm COATE - Andrew KLEIT, The Economics of the Antitrust Process, Boston, Dordrecht, London 1996. And among the Central-European economic thought see for example František SCHILLER, Kartely a trusty $\vee$ Rakousku, in: Obzor národohospodářský XV, 1910, 331-337, 415-425; Jiří HEJDA, Struktura dnešního hospodářství, in: Obzor národohospodářský XXXIV, 1927, 810-827. 
achieve their partial goals. ${ }^{19}$ The ultimate intension of a cartel is to monopolize the whole field and generate monopolistic profit. The question is, however, how effectively a cartel can use the aforementioned tools and whether this can be considered to be a stable and permanent market structure which is able to use the given tools in the long term?

\section{The role of the State in Cartel Creation}

Cartel stability and the option of utilizing the aforementioned tools are largely connected with government measures. It is therefore very important to distinguish between a cartel which arises spontaneously from a market process and a cartel which arises as a consequence of a government decision. Mainstream economic theory tends to see a cartel as a market structure which is able to limit production, exclude competition and set prices. This view leads to attempts to regulate cartels and prohibit their collusive behavior. The period after 1873 was no different in this regard. This period, sometimes known as the "modern cartel era", was more a period of government created cartels than spontaneously created ones. Despite the fact that most economists at that time knew this, the role of the customs tariff policy, for example, was largely underestimated. ${ }^{20}$ The process of cartel creation appeared to be endogenous in terms of market process and, according to the economic thought of that time, it mainly involved spontaneous cartel creation with just a small amount of state intervention. However, if this involves a spontaneous cartel creation process, a cartel is unable to make full use of the tools which standard economic theory ascribes to it. The exogenous barriers created by the government are needed for a cartel to have the option of acting within the economic model. However, this most certainly did not involve completely spontaneous cartelization, because the role of the state's customs policy was not completely negligible. We can assume that the call for cartel regulation thus arises from another misunderstanding of the theoretical aspects of cartelization. It is therefore more than necessary to explain the circumstances under which a cartel can and cannot exploit its position.

\section{Cartel Pricing Policy and the Restriction of Production}

Price agreements are naturally a basic cartel tool. It is assumed that a cartel can use its pricing policy against competitive producers on the one hand and against consumers on the other hand, provided the cartel eliminates the competition from the market. This approach to cartels implies that a cartel has the option and funds available to set prices in a similar way to a monopoly. However, this statement is only partly true. If a cartel is created spontaneously and not as a result of government intervention, it logically cannot ignore consumer demand. However, this demand is often forgotten within the framework of the

19 Pascal SALIN, Ekonomická harmonizace, Praha 2003, 137.

20 ŠEVČíK, 22. Ševčík, analogous to Robert Liefmann, concludes that customs tariff policy is in fact insignificant. There is no doubt that it is possible to argue that domestic producers who are not organized within a cartel structure can also increase their prices, if the government increases customs tariffs. However, when considering a cartel's power to set monopolistic prices, the cartel will always increase prices higher than any producer in a competitive environment. 
standard economic theory about cartels. That was also the case in Central European economic thought, which largely ignored individualism. As a consequence, this could lead to the total neglect of the role of demand in relation to cartel pricing policy. ${ }^{21}$ However, Pascal Salin and Murray Rothbard warn that it is impossible to ignore the role of demand in the case of spontaneously created cartels. ${ }^{22}$ As such, if demand is elastic, the cartel will be unable to set and control prices. Therefore, it only depends on whether the consumer increases the elasticity and in doing so also increases the pressure on price reductions, even if the market is organized in a cartel structure. In this situation, a cartel can be seen as a reaction to specific consumer demand and reduced production, in which case the associated price increase is merely a consequence of the low elasticity.

Thus, the question remains as to what extent a cartel can use its pricing policy against competing producers. It is assumed that a cartel cuts prices under the cost level (discriminatory low prices) for a certain period and in doing so eliminates any other producers who are not part of the cartel. Even in this case, the role of demand cannot be ignored. The pressure on increasing the amount of demand rises along with the fall in prices and this then results in an increase in production. If the producers who are not part of the cartel are able to keep up, the prices for production factors will also fall over the long term which will enable the producers to stay in the market in spite of the existence of the cartel..$^{23}$ If the role of demand is not ignored, the effect of the process of decreasing prices in order to eliminate competition is not so unequivocal. This is because room for competition is created as a consequence of the increased amount of demand and the fall in input prices. The cartel's pricing policy towards consumers or other producers requires the existence of some barriers, if it is to be truly effective.

\section{Market Entry Barriers}

If a cartel's effective collusive behavior is conditional upon the creation of market entry barriers or any other barriers, it becomes very important to distinguish between barriers created by cartel itself and those created by government intervention. The discriminatory low prices mentioned above are considered to be one possible barrier, but, as we can see, this is a short-term solution and not always an effective one. Increasing prices without the existence of barriers is also considered to be a short-term arrangement. One of classic

21 Robert LIEFMANN, The Chief Problem of Economic Theory, in: The Quarterly Journal of Economics, 36, 1922, 2, 335; Karel ENGLIŠ, Noetická kritika rakouské nauky o hodnotě, in: Obzor národohospodářský XXXVII, $1933,361-378$. Rejection of so-called imputation theory can lead to the refutation of individualism. According to Austrian value theory, as defined by Carl Menger, the prices of goods are set retroactively from consumption to production which implies the non-negligible role of the consumer as an individual. In comparison with Menger, Engliš and Liefmann criticized excessive individualism and stressed the role of the state in the process of price setting. For a detailed description of Austrian value theory, see, for example, Carl MENGER, Principles of Economics, Auburn 2007.

22 SALIN, 139; Murray ROTHBARD, Man, Economy, and State with Power and Market, Auburn 2009, $636-643$.

23 Cyril HORÁČEK, K otázce kartelové, in: Obzor národohospodářský l, 1896, 3-5. Some authors like Horáček or Hotowetz became aware of the fact that the prices for production factors will fall. However, Horáček considered a cartel to be a stable structure and did not assume that competition would enter the market as a consequence of the fall in the production factor prices. His view of cartel stability was then criticized, for example, by Vojtěch Hořínek. See Vojtěch HOŘíNEK, K otázce kartelové, in: Obzor národohospodářský I, 1896, 23-34. 
options for creating market entry barriers is the monopolization of input suppliers. This monopolization involves a cartel being the sole and only consumer of these inputs. According to economic theory, a cartel can use similar practices in the case of bank credit. ${ }^{24}$ It is possible to admit that such a situation could theoretically arise, but only provided the influence of international trade is ignored. Any such premise is unrealistic in a situation where a free market exists. Cartel critics can, of course, argue that the "forced" participation in international trade increases the costs for producers who are not a part of the cartel and therefore disadvantages them greatly. However, this is not necessarily a valid assumption. It is also possible to argue that any such criticism implicitly presupposes the existence of a homogeneous product. On the other hand, Salin has shown that cartels display optimal degrees of product differentiation. ${ }^{25}$ To put it more precisely, the cartelization trend is based on product homogenization, but this is not absolute and it is also not permanent given the supposition of a free market, because the cartel organization enables the differentiation of production at any time based on changes in consumer demand. A competing producer who becomes dependent upon participation in international trade as a consequence of the cartel's activities always has the option of differentiating its production. A further important fact is that, when taking the existence of international trade into account, foreign producers place pressure on the domestic cartel and in doing so limit its options for collusive behavior. The cartel itself therefore does not have the option of creating effective long-term market entry barriers and it similarly does not have the option of using its collusive behavior to eliminate the existing competition, if we assume the existence of a free market.

The government can intervene in such a situation and create the barriers. As mentioned above, the government can create these barriers either at its own instigation or under pressure from producers. The cartel organization has better conditions for negotiating any such barriers than an independently active commercial subject. With regard to the cartelization which took place in Central Europe after 1873, the state's customs tariff policies are a perfect example of how the state can create these barriers. Increased tariffs constrain international trade and enable a cartel to resort to long-term collusive behavior which it could not have undertaken in a free market. Of course, tariffs are not the only tool which can be used by the government to create certain barriers which enable a cartel to practice "unfair competition". Other such tools include those which regulate international trade, for example export and import quotas or the granting of concessions and the creation of patents and standards which can influence not only foreign competition, but also domestic production. Naturally, the government has the option of keeping these barriers in place as long as it wishes and in doing so it essentially grants privileges and creates space for cartels which can then abuse their position. ${ }^{26}$ However, economic theory tends to attribute certain

24 For more about the monopolization of suppliers and about banking, see for example WINTER, 31-36 and HEXNER, 7.

25 SALIN, 146-147.

26 Ludwig von MISES, Lidské jednání: Pojednání o ekonomii, Praha 2006, 332. Mises accented the government's influence leading to cartel creation. Despite the fact that some cartels can be created without the contribution of the government, its role is absolutely indispensable. Hexner partially stands against Mises. He acknowledges the existence and role of government barriers, but he is convinced that a cartel is able to make full use of its collusive behavior without the help from the government, especially in the case of consumer surplus drain. 
behavior to the cartel which is only possible within the frame of government measures. This "confusion" then frequently results in calls for the regulation of cartels.

\section{Regulation Versus Deregulation}

There are many grounds for regulation. Cartels are usually criticized for draining the consumer surplus. This is related to the existence of economies of scale. ${ }^{27}$ According to common opinion, cost savings should be projected into price decreases, so that not only cartel producers, but also consumers can benefit from the existence of said economies of scale. However, cartels are not motivated to reduce prices (because of the low elasticity of demand) and this consequently leads to regulation. ${ }^{28}$ The tendency to regulate a cartel exists, even if there are no price increases, which also logically implies the probability of calls for regulation in the case of price increases. Cartel regulation is also required when market entry barriers are about to be created. However, this depends on whether or not the cartel has sufficient resources to create them. A cartel can then be regulated in various ways. The first option is to prohibit cartel agreements as a whole as in Great Britain and the United States or to punish the cartel for exploiting its market power. Another interesting option is to create a so-called latent competition, which would keep the cartel under competitive pressure in order to preclude its ability to engage in collusive behavior. ${ }^{29}$ Forced cartelization also cannot be left out, because this is a solution which has been adopted and which enables the state to control the whole industry. If the prohibition of cartel agreements is left to one side, two regulation options are left. This means either forced cartelization or latent competition. If a cartel is unable to create market entry barriers and set prices over the long term, it is relatively simple to regulate it using latent competition; in other words, to use the pressure of competition. It is sufficient to eliminate the government created market entry barriers. By eliminating tariffs, imports become cheaper which means that foreign producers can easily compete with domestic producers, even if a cartel organization or single monopolist producer exists. Liberalization of import quotas brings similarly positive consequences. Domestic competitors would benefit from the simple abolishment of the issuance of permits for commercial activities, as would also be the case if the issuance of patents was abolished.

Market deregulation in general can be an effective way of "regulating" cartel behavior and it is not necessary to implement the complicated regulation of the cartel itself. However, another solution which has actually been implemented is forced cartelization. The fears concerning the efforts of the monopolizing industries have essentially been realized by means of the use of forced cartelization. Whereas there are specific positive effects from

27 SALIN, 143. Salin criticizes the way of seeing economies of scale as an assumption for cartel creation. Salin himself holds the view that cartel creation is due to subadditivity. On this basis (if it exists), the number of producers falls, because that is the most efficient solution at the given moment. However, cartel creation under the principle of subadditivity does not imply a permanent state.

28 HORÁČEK, 3-5. Horáček assumed that "the sovereignty of capital" should be constrained. In his opinion, capital should also fulfill some social duties. It can be said that mainstream economic thought at that time rejected individualism as a whole.

29 Robert LIEFMANN, Monopoly or Competition as the Basis of a Government Trust Policy, in: The Quarterly Journal of Economics, 29, 1915, 2, 308-325. 
the competitive environment in the case of deregulation, forced cartelization presents several serious problems. ${ }^{30}$ If the intention of the regulation is to simplify government market control, this can be considered to be an acceptable solution. However, it is important to focus on the consequences which are not initially obvious. Compared to deregulation, forced cartelization is a very costly solution due to the necessity of maintaining a bureaucratic structure to control the cartelized industries. ${ }^{31}$ Moreover, the effectiveness of such actions is fairly disputable, if we take other regulations into account. Forced cartelization combined with a high customs tariff policy creates legal privileges for cartels which are therefore able to exploit their position, especially in relation to consumers (with monopolistic prices), because the competition has essentially been excluded.

Regulation in the form of forced cartelization therefore necessarily implies the need for further regulations, for example price regulation. Forced cartelization fundamentally changes the motivation of the cartels. They are motivated to increase prices rather than to increase the quality of their production. As well as price regulation, room then opens up for technical standards and other measures which would ensure a certain quality of production. It is important to mention that forced cartelization changes the motivation of cartels in two ways; by eliminating competitive pressure and by "forcing" the cartelization in the first place. Both of these factors cause a fall in motivation. The government is therefore forced to regulate on the basis of its previous regulations. A significant risk of inflation of regulation and bureaucracy arises due to the fact that it is very hard to predict the consequences of any regulation. On the other hand, there is no change in motivation when barriers are removed or, if there is any change, this cannot involve a long-term or permanent fall due to the ongoing presence of latent competition..$^{32}$ The case of a spontaneously created cartel therefore cannot be seen to be identical to the case of forced cartelization. ${ }^{33}$

\section{The Process of Forced Cartelization in Central Europe}

In conclusion, forced cartelization may be an inappropriate form of regulation. Only a few economists, such as Hotowetz for example, have fully realized the risks associated with cartelization. On the other hand, many representatives of Czech economic thought have supported the regulation of cartels and even forced cartelization. Karel Engliš was one of

30 For more about the market process and the entrepreneurial environment, see Israel KIRZNER: Jak funguji trhy, Praha 1998, 43-46. Kirzner develops the Austrian theory of the entrepreneur. It consists of a dynamic theory of entrepreneurial discovery which stands against the neoclassical static theory of perfect competition. Consequential motivations can be defined, provided competition is considered to be a process and not an instantaneous state.

31 HOTOWETZ, 31-36; STIGLER, 3-21. But bureaucratic control is consequently associated with the asymmetry of information and the risk of regulatory capture.

32 For more about the question of granting legal privileges (with applications concerning the production of money), see Friedrich August HAYEK, Soukromé peníze: Potřebujeme centrální banku?, Praha 1999; Jörg Guido HÜLSMANN, The Ethics of Money Production, Auburn 2008. For more about the motivation of producers under governmental bureaucratic supervision, see Ludwig von MISES, Byrokracie, Praha 2002.

33 Jozef FALTUS, Nútená syndikalizácia československého priemyslu v 30. rokoch, in: Hospodářské dějiny - Economic History, 20, 1992, 167-176. Faltus presumes that both cartel structures work in the same way from an economic point of view and that the differences are only at the legal level. However, this approach fully ignores the aspect of the motivation created by legislation. The same organizing structure in an industry does not necessarily imply the same motivation, because exogenous factors such as the legal framework must be taken into account. 
the great supporters. ${ }^{34}$ Mass cartelization therefore occurred in all industries in Czechoslovakia due to the broad support for it. Cartels had already emerged before in traditional concentrated industries (for example, the iron or sugar industries). The customs policy was initially modeled on these cartels, specifically by means of the so-called Enabling Act from 1933 which was consequently followed by the Cartel Act. The environment for cartelization was initially created, similarly as in 1873, and the legal acknowledgement of the cartels then followed. The primary intention was to limit overproduction, which led to a fall in prices. ${ }^{35}$ State regulation therefore also focused on less concentrated industries, which were more competitive. This competitive environment was perceived very negatively during the period of the ongoing crisis. As such, some very unusual cartels were created, such as the sheep's milk cheese cartel, the margarine cartel or the ground red pepper cartel. Cartels were also created in the glass and textile industries. By the end of the 1930s, competition as a whole had essentially disappeared. ${ }^{36}$

Forced cartelization emerged in Germany as well within the framework of the Nazis' economic policies. However, this cartelization involved the completion of a process which had already begun during the Weimar Republic. ${ }^{37}$ The German government's options were rather limited when it came to economic policy and therefore cartels, which have a significant tradition in Germany, could be used as an efficient deflation brake after the German hyperinflation. ${ }^{38}$ At the end, the forced cartelization in Nazi Germany had the characteristics of a centrally planned economy where the role of private property was considered to be only a formality, because the cartels were forced to fulfill the orders of the government which was to all intents and purposes a monopolistic consumer. ${ }^{39}$ Whereas a fully centrally planned economy was not the goal in Czechoslovakia, these intentions were greatly simplified in Germany by forced cartelization. By the same logic, forced cartelization in Czechoslovakia therefore simplified the controlling and planning of the Czechoslovak economy during the era of the Protectorate. The effect of forced cartelization in the process of nationalization after 1945 also cannot be ignored. The Nazis were able to organize the Austrian econo-

34 lbidem, 168. According to Faltus, government economic intervention was a right thing to do at that time. Furthermore, he mentions Engliš himself, who presumed that forced cartelization does not precede the collectivization of production. However, it is very important to realize that the state manipulates property rights in that case and that forced cartelization is in fact a precursor to collectivization, just as spontaneous cartelization can lead to mergers.

35 Ibidem, 169.

36 To fully exclude competition it is not necessary to realize forced cartelization in all the industries. The crucial thing is the cartelization of the primary commodity industries and the tariff protection of such cartels at the same time. Such cartels can continue to act as a monopoly which implies its pricing policy options. Under these circumstances, it is far more convenient for producers in associated industries to cartelize among themselves and not to compete when it comes to the primary commodity provider. Forced cartelization therefore leads to another wave of cartelization.

37 One of the chief cartels - IG Farben - was created in 1925. Also the number of cartels created by 1929 was significantly higher than in other states in Central Europe.

38 For more about German deflation policy see Dietmar PETZINA, Hospodářskopolitická strategie za světové hospodářské krize. Srovnání situace v Německu a v Československu, in: Konkurence a partnerství: Německé a československé hospodářství v letech 1918-1945, Boris BATH - Josef FALTUS - Jan KŘEN - Eduard KUBU゚ (eds.), Praha 1999, 157-171.

39 Philip C. NEWMAN, Key German Cartels under the Nazi Regime, in: The Quarterly Journal of Economics, 62, $1948,4,577$. 
my similarly to the economy in Czechoslovakia. The customs policy was revised from the beginning of the 1930s, international trade was constrained (by the so-called 'Einfuhrverbotsverodnungen') and as such a suitable environment for cartelization was created. The skeptical opinions of cartels were gradually left behind and regulations aimed at meeting the state plan were created. ${ }^{40}$ The transition to a centrally planned economy may be considered to be one of the unintended consequences of forced cartelization, which the Nazi, and latterly the communist (in Czechoslovakia), regime could "profit" from.

\section{Conclusion}

Forced cartelization brings negative consequences, both at a theoretical and a practical level. This can be quite easily illustrated in the region of Central Europe. The trigger mechanism for the processes which led to forced cartelization was the original miscomprehension of the course of the business cycles. The primary misunderstanding brought with it other misunderstandings and the economic theory based on these incorrect assumptions began to be projected into economic policy. ${ }^{41}$ Understanding a crisis as an overproduction crisis leads to protectionist policies which limit international trade. These restrictions are followed by a wave of cartelization. The process of cartelization is further considered to be a valuable tool for limiting deflation and overproduction on the one hand, but also as a monopolization risk on the other hand. The risks resulting from cartels and the incomprehension of the basic principles, which enables cartels to abuse their power, lead to further call for regulation. Instead of market deregulation, a process of massive regulation occurs, leading to forced cartelization which creates monopolistic privileges for domestic producers. This implies the need for the further regulation and bureaucratic control of the market, which may eventually completely disappear, as we saw in Central Europe in the interwar period.

Government efforts to prevent the supposed inefficiency of cartels eventually lead to very costly and clearly inefficient regulation. It is therefore important to understand that a cartel cannot use the tools defined by the standard economic theory by itself. The conditions for the use of these tools are only created by government intervention. It is also important not to ignore the role of consumer demand, which is one of the causes of cartel creation. In a free market, a cartel can only use its powers, if the demand is inelastic and the cartel is therefore limited by consumer preferences. If we do not ignore demand, it is also possible to view a cartel as a market structure which reflects the demand for saving scarce resources and not only as a structure which has been created to monopolize the whole industry.

The story of Central Europe in the periods of deep crises, after the 1873 and 1929, relatively clearly illustrates the failures of economic policy which is based on a deficient understanding of specific phenomena in the mainstream framework of Central European eco-

40 Gertrude ENDERLE-BURCEL, "Planwirtschaft" als Krisenbekämpfung. Aspekte österreichischen Staatsinterventionismus 1930-1938, in: Der Markt im Mitteleuropa der Zwischenkriegszeit, Alice TEICHOVÁ - Alois MOSSER - Jaroslav PÁTEK (eds.), Praha 1997, 379-391.

41 A significant number of economic and legal theorists were also active also in politics after the disintegration of Austria-Hungary. From the Czechoslovak theorists, it is possible to mention Hotowetz, Winter, Horáček or Engliš, who were ministers after 1918. 
nomic thought. The economic measures then led to unintended consequences. A loss of respect for property rights on the part of the government is a critical consequence of such policies. I therefore believe that government actions during the struggle against the crisis made the transition to a centrally planned economy much easier, because there is only a thin line between forced cartelization and collectivization.

\begin{abstract}
The aim of this essay is to show incorrect steps of economic policy based on misunderstandings of Central European economic thought between the crises in 1873 and 1929. After-crisis governmental protectionism led to a massive cartelization which required another government regulation. The process of regulation and protectionism resulted in forced cartelization and the market has disappeared by the year 1938. The conclusion of this paper essay states that liberalization and market deregulation would be a better solution how to regulate cartels because the process of forced cartelization could lead to a transition process to a centrally planned economy.
\end{abstract}

\title{
Keywords
}

Forced Cartelization, Central Europe, Tariff Policy, Economic Crises, History of Economic Thought

\section{References}

AYRES, lan: How Cartels Punish: A Structural Theory of Self-Enforcing Collusion, in: Columbia Law Review, 87, 1987, 295-325.

COATE, Malcolm - KLEIT, Andrew: The Economics of the Antitrust Process, Boston, Dordrecht, London 1996.

ENDERLE-BURCEL, Gertrude: "Planwirtschaft" als Krisenbekämpfung. Aspekte österreichischen Staatsinterventionismus 1930-1938, in: Der Markt im Mitteleuropa der Zwischenkriegszeit, TEICHOVÁ, Alice - MOSSER, Alois - PÁTEK, Jaroslav (eds.), Praha 1997, 379-391.

ENGLIŠ, Karel: Deflační a racionalisační krise, in: Obzor národohospodářský XXXVI, 1932, $1-24$.

ENGLIŠ, Karel: Noetická kritika rakouské nauky o hodnotě, in: Obzor národohospodářský XXXVII, 1933, 289-303, 361-378.

FALTUS, Jozef: Nútená syndikalizácia československého priemyslu v 30. rokoch, in: Hospodářské dějiny - Economic History, 20, 1992, 167-176.

FISCHER, Paul Thomas - WAGENFÜHR, Horst: Kartelle in Europa (ohne Deutschland), Nürnberg 1929.

HAYEK, Friedrich August: Soukromé peníze: Potřebujeme centrální banku?, Praha 1999.

HEJDA, Jiř́: Struktura dnešního hospodárství, in: Obzor národohospodářský XXXIV, 1927, 810-827.

HEXNER, Ervín: Československé kartely, Praha 1933. 
HORÁČEK, Cyril: K otázce kartelové, in: Obzor národohospodářský I, 1896, 3-5.

HOŘíNEK, Vojtěch: K otázce kartelové, in: Obzor národohospodářský I, 1896, 23-34.

HOTOWETZ, Rudolf: Kartely a stát, in: Obzor národohospodářský II, 1897, 209-212.

HÜLSMANN, Jörg Guido: The Ethics of Money Production, Auburn 2008.

KIRZNER, Israel: Jak fungují trhy, Praha 1998.

KOHOUT, Pavel: Finance po krizi: důsledky hospodářské recese a co bude dál, Praha 2009.

KOVACIC, William - SHAPIRO, Carl: Antitrust Policy: A Century of Economic and Legal Thinking, in: Journal of Economic Perspectives, 14, 2000, 1, 43-60.

LIEFMANN, Robert: Monopoly or Competition as the Basis of a Government Trust Policy, in: The Quarterly Journal of Economics, 29, 1915, 2, 308-325.

LIEFMANN, Robert: The Chief Problem of Economic Theory, in: The Quarterly Journal of Economics, 36, 1922, 2, 335-342.

MACGREGOR, David: Recent Papers on Cartels, in: The Economic Journal, 37, 1927, 146, 247-254.

MENGER, Carl: Principles of Economics, Auburn 2007.

MISES, Ludwig von: Lidské jednání: Pojednání o ekonomii, Praha 2006.

MISES, Ludwig von: Byrokracie, Praha 2002.

MISES, Ludwig von: The Historical Setting of the Austrian School of Economics, 2003, URL: http://mises.org/etexts/histsetting.pdf (visited: June 2014).

NEWMAN, Philip C.: Key German Cartels under the Nazi Regime, in: The Quarterly Journal of Economics, 62, 1948, 4, 576-595.

PANEŠ, Patrik - ŠíMA, Josef: Výzvy antimonopolní politiky v 21. století, in: Acta Oeconomica Pragensia, 13, 2005, 3, 69-80.

PETZINA, Dietmar: Hospodářskopolitická strategie za světové hospodářské krize. Srovnání situace $v$ Německu a $v$ Československu, in: Konkurence a partnerství: Německé a československé hospodářství v letech 1918-1945, BATH, Boris - FALTUS, Josef - KŘEN, Jan - KUBU゚, Eduard (eds.), Praha 1999, 157-171.

ROTHBARD, Murray: Man, Economy, and State with Power and Market, Auburn 2009.

SALIN, Pascal: Ekonomická harmonizace, Praha 2003.

SCHERER, Frederic M. - ROSS, David: Industrial Market Structure and Economic Performance, Boston 1990.

SCHILLER, František: Kartely a trusty v Rakousku, in: Obzor národohospodářský XV, 1910, 331-337, 415-425.

STIGLER, George: The Theory of Economic Regulation, in: The Bell Journal of Economics and Management Science, 2, 1971, 1, 3-21.

ŠEVČík, Otakar: Kartely, Praha 1913.

VIŠKOVSKÝ, Karel: Zdražování životních potřeb, in: Obzor národohospodářský XII, 1907, 21-30, 82-87, 127-137, 171-178.

WINTER, Lev: Donucovací prostředky kartelu, in: Obzor Národohospodářský XVIII, 1913, $31-36$. 